DOI: https://doi.org/10.34069/AI/2021.46.10.9

How to Cite:

Virchenko, T., \& Kozlov, R. (2021). Generation related self-identity of Lesia Ukrainka (Based on her epistolary heritage). Amazonia Investiga, 10(46), 101-108. https://doi.org/10.34069/AI/2021.46.10.9

\title{
Generation related self-identity of Lesia Ukrainka (Based on her epistolary heritage)
}

\section{Поколіннсва ідентичність Лесі Українки (на основі її епістолярної спадщини)}

Received: September 15, 2021

\section{Abstract}

The need to talk about the generation related selfidentity of those writers who lived at the change of the century became more acute, because "fin de siècle" is the period of modernization of literature. The objective of the research is both historic-literary and purely theoretical. If in the first area we have to find out the individual identity of Lesia Ukrainka with a certain literary generation, and in the second area one should answer the question of whether the selfidentification of the writeress with a certain literary generation can become the cornerstone for writing the history of literature. The process of working with the contents of letters was carried out with the help of systematic interpretation and hermeneutic reading. The main result of the research is the possibility to state that Lesia Ukrainka respected the experience of the representatives of the previous generation, but she desired to be appreciated by critics as part of the present generation gives reason to think that the writeress still identified herself as the representative of modernism.

Keywords: self-identification, generation, "fin de siècle", Lesia Ukrainka, modernism.

\section{Introduction}

David Perkins asserted that "we write literary history because we want to explain, understand, and enjoy literary works" (1992, p. 178). Those histories of Ukrainian literature that have
Accepted: October 29, 2021

Written by:

Tetiana Virchenko ${ }^{28}$

https://orcid.org/0000-0001-7953-2285

Roman Kozlov ${ }^{29}$

https://orcid.org/0000-0001-5912-9106

\section{Анотація}

Потреба говорити про поколіннєву самоідентичність письменників, які жили на межі століть загострюється, оскільки "fin de siècle" - це період модернізації літератури. Мета дослідження $\epsilon$ водночас істориколітературною і суто теоретичною. У першій сфері ми повинні з'ясувати особисте ідентифікування Лесі Українки 3 певним літературним поколінням, у другій відповісти на питання, чи може самоідентифікація письменниці 3 певним літературним поколінням стати наріжним каменем для написання історії літератури. Робота зі змістом листів здійснювалася за допомогою систематичного тлумачення та герменевтичного читання. Основним результатом дослідження $є$ можливість стверджувати, що Леся Українка поважала досвід представників попереднього покоління, однак прагнула бути оціненою критиками як частиною нинішнього покоління, що дає підстави вважати: письменниця все ж ідентифікувала себе як представниця модернізму.

Ключові слова: самоідентифікація, покоління, "fin de siècle", Леся Українка, модернізм.

recently appeared in the scientific space are designed not for the general reader, but for students of philological specialties of higher educational establishments, or for the scientific

\footnotetext{
${ }^{28}$ Dr. in Philology, Borys Grinchenko Kyiv University, Ukraine.

${ }^{29}$ Dr. in Philology, Borys Grinchenko Kyiv University, Ukraine.
} 
community. The personality of each writer has its own "label", which shows the belonging to a particular literary generation, and the chronological boundaries are one of the key elements. At the same time, self-identification of the writer with either the literary period or generation is left unattended. The need to talk about the generation related self-identity of those writers who lived at the change of the century became more acute, because "fin de siècle" is the period of modernization of literature, the time of crisis and changes, the moment of the merging of inherited traditions and innovation.

This study is also related to the theoretical question of whether it is possible to write history of literature being managed not by historical and chronological criterion, but rather a generation related one. After all, the history of Ukrainian literature already has such attempts, for example, in Serhii Yefremov's works.

\section{Theoretical Framework}

We are in favor of the notion "generation" made by Ihor Kon: "Regardless of the historical usage of the notion "generation", there is also a symbolic one, where it is not so chronological community emphasized but rather community of life experience and feelings" (1976, p. 48). Tudor Vianu convinced:

Under the discrepancy of chronological and biological generations, literary generations can be recreated, that is to say, solidarities among people who, living at the same time, irrespective of their age, harbor similar hopes and contribute to the same work. (1936, p. 7).

But this opinion obviously needs clarification made by Laurentiu Ichim: "the members of a literary generation share the same beliefs and literary orientation, they choose (relatively) similar creation techniques and text rendition strategies, and believe in the same purpose of the artistic act" (2012, p. 285). Larysa Demska-Budzuliak analyzed understanding of the essence of a literature generation in the Polish literature encyclopedia and in the work Generation Change - Reality of the Problem? showed observation that a generation is a group of artists that have common historical experience, thus, are contemporaries, however, not always of the same age, share the same ideals, aesthetic programs, etc. (2005, p. 171). This view of the Ion Bogdan Lefter is also interesting:
A literary generation is made up of writers whose works emphasize a common formula (...) whose works reveal significant similitudes and can be regarded as embedment's of a single structural pattern. Therefore, I consider the literary generation firstly a generation of texts, then a generation of writers. $(2005$, p. 73$)$.

Literary scholars who study the history of literature as a theoretical issue consider the possibility of the existence / writing of the history of literature as one of the aspects of the problem. Yuliia Yemets-Dobronosova states:

The possibility (and possibilities) of the history of literature are connected with the question of identity. And when it comes to identity, one should see in it not something native and unchangeable (identity-essence), but volatile and gained, constantly renewable and selfabnegation (identity-formation, identityprocess). (2010, p. 3).

Perhaps that is why the idea of returning the literary history to the generations' paradigm is often heard (Hentea, 2013).

The history of literature is the history of separate personalities and their works. It is obviously that writer's identity cannot be stable, because the personality develops. The same cannot be said about the definition of the writer's identity by literary scholars. The personality of Lesia Ukrainka in this aspect is very complicated. Lukash Skupeiko precisely formulates the existing problem:

Such uncertainty and, for the most part, the confusion about the belonging of Lesia Ukrainka to a particular literary school or stylistic flow is complicated by the fact that the writeress herself is known to have repeatedly declared her direct involvement in the 'new-romantic school'. Obviously, this points at the detachment from 'old romanticism', realism, and modernism, which is believed to be often perceived as a manifestation of 'painful decadence'. (2007, p. 190).

An appeal to the histories of Ukrainian literature testifies that it was difficult for the authors to reach a unanimous opinion about Lesia Ukrainka's generational affiliation. Ivan Franko in Ukrainian-Russian (Little Russian) Literature (1898) stated the arrival in the early 90s of a new generation, "which identifies talented belletrists Vasyl' Chaichenko, Lesia Ukrainka, Volodymyr Samiilenko, A. Krymskyi, M. Shkolychenko, T. Zinkivskyi, Gr. Kovalenko, Liudmyla Starytska" 


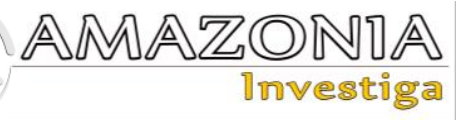

(1984a, p. 86). In another work Ukrainians (1906) Ivan Franko names three generations: 60s, $70 \mathrm{~s}-80 \mathrm{~s}, 90 \mathrm{~s}$. The $90 \mathrm{~s}$ generation represents the "latest phase of national development" and constituted by B. Grinchenko, M. Kotsiubynskyi, P. Leontovych, V. Samiilenko, Lesia Ukrainka, V. Stefanyk, N. Kobrynska, O. Kobylianska, Martovych, Yatskiv, B. Lepkyi. (1984b, p. 192) Serhii Yefremov in History of Ukrainian Writing (1911-1929), characterizing the generation of the eighties, states:

Generation (...) is not very numerous, though it is not at all reminiscent of the sluggish and frail generation of the all-Russian intelligentsia of the same time. Ukrainians of the eighties are marked, on the contrary, by a cheerful spirit, mobility, perseverance, with which they relentlessly go to their goal, although they bear the double oppression - and political reaction, and national oppression. (1995, p. 385).

The researcher includes in this generation B. Grinchenko, Zinkivskyi, D. Markovych, N. Kobrynska, S. Kovaliv, T. Borduliak, Tsehlynskyi, Or. Levitskyi, V. Samiilenko, P. Hrabovskyi, Lesia Ukrainka, A. Krymskyi and L. Vasylevska (1995, p. 384). Mykola Zerov in the article Lesia Ukrainka and the Reader (On the Occasion of the Fifteenth Anniversary of her Death) skeptically evaluates this view:

What are those names for us now? Some are lost and appear only in special works as typical expressions of the day, others - have become a lecture for youth and no longer bother anyone who has outgrown the sixteenth spring - while Lesia Ukrainka lives, causes heated controversy, and critic-publicist abroad tries to do her companion, preacher la bella vendetta and many things that the poet would be sincerely horrified. (2003, p. 605).

In 1913, Mykola Yevshan's article Lesia Ukrainka was published in the Literary-Scientific Bulletin, in which the 1880s are characterized not so optimistically:

I must say that the 80s when twelve-year-old Lesia first entered the literary field - was a dead time for Ukrainian literature, and especially for poetry. There was no creative impulse in the literary production of that time, people walked the earth too much, the reaction nailed them to the ground too much. (1998, p. 161).

Instead, the researcher characterizes the end of the nineties as a time when the writeress "consciously went her own way", while having her own style, "a completely separate physiognomy” (Yevshan, 1998, p. 163).

This idea acquires clearer features if we comprehend the definition of the term "generation" proposed by Mykola Yevshan in the article The Struggle of Generations and Ukrainian Literature (1911):

Each generation is a new, completely separate world. From his speech begins a new life, it cannot admit any other life than its own. It does not want to know anything about the experience of older generations, it does not want any science, no mentoring of history - it itself, from the very beginning, wants to experience everything. Because it is counted only with its own experience, only what it itself has experienced has value for it. Therefore, despite any warnings from the elders, despite the predictions and the most difficult obstacles, it is ready at any moment to fully develop its adventurous, so to speak, temperament, to do things dictated not by reason, but only youthful, reckless impulse, even madness. That is the beauty and charm of that struggle. (1998, p. 176) According to M. Yevshan, the change of the eighties and nineties is indistinct because we did not have the struggle of generations, that strong, spontaneous movement, which comes in a wave every 30 years. New generations appeared imperceptibly, passed unnoticed, so that even the change of generations in the full sense of the word cannot be said. The reasons are clear. Nobody here knew, did not feel in himself at least instinctively his right to take the helm of life from the weak, though experienced hands of his father, he was afraid to turn the stream of life in his direction. (1998, p. 177).

Leonid Biletskyi in the exploration Three Silhouettes: Marko Vovchok - Olha Kobylianska - Lesia Ukrainka expressed a rather paradoxical opinion about Lesia Ukrainka's relations with her generation:

By her own nature and strength of spirit, she was the ruler of the entire young Ukrainian generation of that time, its leader, its soul and conscience. However, that generation did not always understand the greatest artist of that time. Only after Lesia Ukrainka's death did she understand who she had lost. (1951, p. 83).

We find a similar paradoxical assessment in the letters of Lesia Ukrainka herself. For example, in a letter to Angelo de Gubernatis from late July to early November 1902, we read: 
Je dois observer que je ne suis plus novice en littérature, il y a longtemps que je me donne aux belles lettres, à la critique et au folklore aussi. Je ne suis complétement ignorée dans les cercles littéraires en Russie, Autriche et Allemagne, mais en Italie - qui est ce qui se doute du nom modeste d'une Lessia Oukraïnka (mon pseudonyme littéraire)? Puis-je esperer de me faire entendre dans une literature ou je suis une "persona ignota"?

[I must observe that I am no longer a novice in literature, it has been a long time since I gave myself to beautiful letters, criticism, and folklore too. I am not completely ignored in literary circles in Russia, Austria, and Germany, but in Italy - who knows the modest name of a Lesia Ukrainka (my literary pseudonym)? Can I hope to make myself heard in literature where I am a “persona ignota"?] (2017, p. 479).

According to Leonid Biletskyi, the process of her entering this generation was influenced by the physical and mental state of the writeress, as well as the feelings and understanding of her contemporaries:

When her illness reaches from under the stellar spheres of dreams into the reality of the real suffering of her sick body and envelops her soul with pessimism of helplessness and inability to fight, then she was saddened by hopelessness as a synthesis of inability to fight and all Ukrainian citizens, including Ukrainian youth of her generation. And then the organic defect of the psyche of helplessness in the souls of her generation was revealed to the poetess. (1951, p. 94).

The team of authors of the Soviet academic history of Ukrainian literature fits Lesia Ukrainka in the context of the beginning of the $\mathrm{XX}$ century. She as poetess opposes other modernist poets, her contemporaries M. Voronyi, O. Oles, M. Cherniavskyi, A. Krymskyi, M. Filianskyi. Lesia Ukrainka, as playwright, finds herself in the circle of V. Samiilenko, L. Yanovska, S. Vasylchenko, A. Krushelnytskyi, O. Oles, and H. Khotkevych. During the discussion of the academic history of Ukrainian literature in 10 volumes (now they are 12), literary critics also asked questions about the context of Lesia Ukrainka's work. Then, in April 2003, it was decided to present a portrait of Lesia Ukrainka in the context of the early XX century, because despite the writeress' compliance with the context of the XIX century, in the latter she will be a foreigner (Skupeiko, 2005, p, 113). Thus, Lesia Ukrainka found herself in the circle of M. Kociubynskyi, V. Stefanyk, O. Kobylianska, V. Vynnychenko, M. Yatskiv. Other sources of identification of the representatives of the generation are memories. Thus, Izidora Kosach-Borysova (the writeress' youngest sister) mentioned that there were never empty conversations and gossips in the family society, so "our parents avoided the society of people who have no other higher interests" (Scrypka, 2004, p. 164). In another memoir, she claimed that there were many prominent people in the Zelenyi Hai, among them such writers as M. Kotsiubynskyi, O. Kobylianska, and V. Stefanyk. Literary novelties were heard and discussed during the meeting:

Of course, the 'green youth' in such cases mostly listened more, which was also interesting and useful. And there were such 'daring' brave people who submitted their remarks, which were not entirely in unison with the statements of already recognized writers. And these writers with a name like Lesia Ukrainka, M. Kotsiubynskyi or O. Kobylianska, seriously, calmly discussed, defended their opinions in disputes even with opponents who were not very competent and calmly listened to their critical remarks. (Scrypka, 2004, p. 183).

Memories of the 90s inevitably lead to the Pleiade circle, which included Lesia Ukrainka, her brother Mychailo, Liudmyla Starytska, Maksym Slavynskyi, and Zinovii Zavileiskyi. All members of the circle wrote poetry and prose, they translated into Ukrainian. Mychailo DraiKhmara in the scientific work Lesia Ukrainka also mentions the activities of the Pleiade, but the researcher differentiated its participants:

In the center were M. Starytskyi, Olena Pchilka [Lesia Ukrainka's mother] and M. Lysenko. From the older generation there were O. Konyskyi, K. Mychalchuk and M. Kovalevskyi, from the younger - Lesia Ukrainka, her brother Mychailo Kosach, M. Slavyns'ky, M. Hrushevskyi, V. Borovyk, Y. Tymchenko, I. Steshenko, O. Cherniakhivskyi, O. Ostrohradskyi, O. Romanov and many others. (2002, p. 48).

In general, it should be noted that M. DraiKhmara turned out to be very observant of Lesia Ukrainka's entourage. Yes, we find out that "of the Ukrainian writers of the older generation Lesia respected Starytskyi and Kulish" (2002, p. 69). The writeress closely followed all the literary novelties, so when Oles' work Over the Dnipro and Shadows of Forgotten Ancestors by M. Kotsiubynskyi appeared, Lesia Ukrainka 


\section{AMAZONIA
1nvestiga}

"was amazed that three things of the same tone and composition appeared almost simultaneously" (Drai-Khmara, 2002, p. 70).

\section{Methodology}

The epistolary heritage of Lesia Ukrainka is interesting for scientists, but research solve very local tasks, and large-scale systemic research failed to appear even after the work of Vitalii Sviatovets The Epistolary Heritage of Lesia Ukrainka: The Letters in the Context of Artistic Creation (1981). Vira Aheieva characterizes the chosen object of our research, as: "Letters written to different recipients sometimes present us with very different levels of self-identification, the author chooses different roles or even masks for herself" (2008, p. 167). In particular, one can find traces of conflicts of generations in private correspondence, based on the self-affirmation of the writeress (2001, p. 89). Indeed, the epistolary testifies to intergenerational contacts, and they, according to J. Ortega y Gasset, are evidence of the generational community.

The objective of the research is both historicliterary and purely theoretical. If in the first area we have to find out the individual identity of Lesia Ukrainka with certain literary generation, and in the second area one should give an answer to the question of whether the self-identification of the writer with certain literary generation can become the cornerstone for writing the history of literature. The potential of such an approach is beyond doubt, since the person has to think of himself/herself in the context of the historical time in which he/she was born.

The object of national histories is not only artistic works, historic-cultural and social processes, but also people. Therefore, the personality of the writer, his/her mindset, which cannot be fully realized without comprehension of selfidentification, should become the object of the research. Positive results of the research of the writer's generation related self-identification will open up new approaches to writing the history of literature, which in its turn will enable to review the specific works in other contexts.

The research contains several semantic blocks. Thus, the introduction outlines the actual problem of the possibility/impossibility of writing the history of national literature; the generational criterion is chosen among others, as the most prospective and less investigated. During the research it is reasonable to carry out an overview of the works of experts in Lesia Ukrainka's works, devoted to the epistolary heritage. The research presents those thoughts concerning the potential of the writeress' letters. The process of working with the texts of letters was carried out with the help of general scientific methods of component analysis, synthesis and the actual historic-cultural method. The letters of Lesia Ukrainka, published in a three-volume edition (2016-2018, ed. by Valentyna Prokip (Savchuk)) served as the material for research. Attention was drawn to the addressees; assessment of the perception by Lesia Ukrainka of the senior colleagues and those writers who entered the literary process at a later date; selfanalysis of own works.

The range of addressees of Lesia Ukrainka is quite broad, but expected - relatives, colleagues, cultural figures. The analysis of the following research shows belonging of these peculiarities to generation, but one can see that Lesia Ukrainka preferred to communicate with her senior colleagues, occasionally to colleagues of the same age. From the representatives of the younger age, one can detach only a few representatives like Hnat Khotkevych, Ostap Lutskyi, Klyment Kvitka, Nadiia Kybalchych.

\section{Results and Discussion}

The writeress' reference to the addressees does not make it possible to trace the differences in the attitude:

I do not call you by your patronymic name, because, to tell the truth, I do not know your patronymic name anyway, and I do not really love this foreign tradition of address. Don't be offended when I call you a friend, because this is the universal tradition to address the companionin-arms, and we both cope with the pen (Ukrainka, 2018, p. 388).

Lesia Ukrainka critically assessed the works of writers who worked at that time: "The trouble of our Ukrainian writers is that they write more than they read, and if they read, then only their works, I do not want to follow their example" (2016, p. 325). The writeress supported periodicals of that times, in particular Ridnyi Krai (Native land). In a letter to her mother we will find an assessment of the older generation: "When 'Ridnyj Kraj' will suffer from Kropyvn[ytskyi] and Myrnyi, it will be a great pity, because it is even worse than to suffer for no good reason in the cause of some soulless writing, which the authors themselves do not understand" (2018, p. 286). 
Lesia Ukrainka had also a low opinion as for The Library of Natalia Kobrynska: "These women's publications are quite narrow-minded" (2016, p. 342). In a letter to her sister O. Kosach from September 1908, Lesia Ukrainka evaluates the work of Nadiia Kybalchych as the work of a minor writeress, but shows concern and care:

As you know, I don't know Kybalchych very well, but it just hurts me to leave her without any help or advice. In addition to the fact that 'for humanity' it is a pity, but also sad that the Ukrainian writeress, and we have not so many tertiary, to neglect people, in any case, talented. (2018, p. 399).

However, the attitude towards the older generation was not as simple as the previous facts show. Ivan Franko had the respect and esteem in the eyes of Lesia Ukrainka: "I never stopped respecting Franko, as a writer and personality" (2016, p. 489).

It makes sense to describe separately the assessment of the work of Olha Kobylianska by Lesia Ukrainka. In May 1899 the writeress addressed a request to Mychailo Pavlyk:

I kindly ask you to send my letter to Ms. Kobylianska, you might know her address. If she does not have any idea of who I am, then please introduce me to her. I have been following her literary progress for a long time and she is very interesting to me as a person and as a talent. Her works are not dilettantism, but true literature. (2017, p. 119).

Subsequently, in the letter directly to Olha Kobylianska it is very clearly shown, that Lesia Ukrainka did not identify the talented writers with the majority:

When one compares your works with Galician ones (I do not mean, for example, works of I. Franko, because he does not belong to the majority); there (in the Galician works) you can find cubby and stove, - you have a mountain hill, a wide horizon). (2017, p. 126).

In the letter to Mychailo Pavlyk dated June $7^{\text {th }}$, 1899, Lesia Ukrainka expressed her opinion about the positive influence of Germany on Olha Kobylianska and asked the addressee to compare the works of Kobylianska with the works "(Holy Lord!) Kovalenko, Katrenko, Kovaliv” (2017, p. 142).

Another personality, whose works are appreciated in the letters - Vasyl Stefanyk: "His articles are good, but unspeakably sad ... in the end, all our literature is not filled with joy" (Ukrainka, 2017, p. 161). It should be noted that Lesia Ukrainka in most cases drew her attention to the works of writers who appeared in the literary process of that time, and only in exceptional cases she was interested in the personality of the writer, when the works were iconic: "I do not know about Mr. Stefanyk, except for his works, but it would be useful if at least there was some biographical summary" (2017, p. 176).

Playwrights-coryphaeus did not remain unnoticed by Lesia Ukrainka as well. Since the writer always dreamed of producing her own plays, the attention was drawn to the activities of troupes of that time, in particular Marko Kropyvnytskyi. In the letter to her mother, Lesia Ukrainka complains that she does not know "which troupe Mr. Kropyvnytskyi has now, is it but disorderly" (2016, p. 465). Later, her assessment will become negative towards the performance of the actors ("The Germans play wonderfully, typically, and already so 'folk' so let our Ukrainian actors hide!” (Ukrainka, 2017, p. 98)), and the dramatists themselves:

I have to admit, that the prospect of writing on the given topic (Mr. St[arytskyi] has the intent already) and together with a person of a completely different literary generation and not similar to my literary methods - is worth than death. (2017, p. 168-169).

And although time moved on, and the cast of the troupe of Marko Kropyvnytskyi kept on changing for the better, the same cannot be said about the quality of the plays, referring to Lesia Ukrainka:

One of these days I was on the new drama of Mr. Kropyvnytskyi named Zaidyholova and returned down in the dumps from there. I felt pity for Zankovetska, who wasted her talent on such things. (2017, p. 223).

One has every reason to state that Lesia Ukrainka sympathized with the modern direction and positioned herself with it. Thus, in the letter to Volodymyr Hnatiuk dated May $30^{\text {th }}, 1900$, Lesia Ukrainka asked:

May your laudatory edition overcome known to me aversion to the 'modernists' and read my translation, I am sure that this original and finely written piece cannot but draw attention to it of even 'outside reader'. (2017, p. 202). 


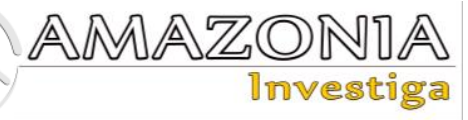

In addition, Lesia Ukrainka believed that the representatives of the "old school" were not able to write in a new way:

I return to literature (...) and I do not know if 'decadent' story of Levytskyi is worth mentioning here, because that is not literature. It is strange, that people think when someone writes 'in a decadent manner', then it gives him/her the right to write nonsense. It would be better if Levytskyi stopped writing in new direction' or satires, because this is not his business, a quick look at him is enough to understand that he is far from 'modern'... I am just amazed at the editorial of 'Visnyk' that printed such a thing, it could have pitied if not its readers, then the glory of the author and avoid rendering him such a nasty service. (2017, p. 223-224).

The "most fashionable" writer M. Yatskiv had a favor in that time. We suppose, that besides the artistic quality, the desire of M. Yatskiv "not to belong to any "school" impressed Lesia Ukrainka" (2017, p. 387). In the letter to O. Kobylianska dated July $2^{\text {nd }} 1903$, Lesia Ukrainka expressed the contemporary opinion on the importance of respect in the writeress' environment. But only surnames of Vasyl' Stefanyk, Ivan Franko and the addressee are presented. The fact that Ukrainian youth from St. Petersburg high schools invited Olha Kobylianska, Lesia Ukrainka, Vasyl Stefanyk to the collection testifies that these writers were perceived by society as one generation.

From the attitude of Lesia Ukrainka to criticism ("I will accept only pieces of advice, and only those which I want" (2018, p. 239)), the following conclusion comes to mind, that in spite of existence of other writers, whom she respected, Lesia Ukrainka felt lonely in literary process, and she slightly believed in the "improvement" of literature of that time, because "our literature and criticism live under abnormal conditions - first of all there is no real reading public behind it" (2018, p. 447-448).

Introspection of own drama works in Lesia Ukrainka's letters underwent specific evolution. First of all, self-reflection is observed in the end of 90s. Secondly, the emotional background of assertations differs: at first this is frictionless statement of adherence to own principles "exclusion of monologues from the new drama" (2017, p. 18); "she did not welcome the term 'reading the monologues" (2017, p. 30). With the course of time emotions are added: "I was on fire when writing it" (2018, p. 251), compassion is expressed towards the fate of her play "Blue Rose".

Lesia Ukrainka did not want anyone to see the traces of subjectivism in her works (it is about her play "Johanna, Khusa's wife"):

The only thing Johanna has is subjective tone towards the teacher - 'et tout le reste est de la litterature'. You can be sure, that my soul has never lived 'In Khusa's house', otherwise I would be dead long time ago. (2018, p. 550).

Referring to Lesia Ukrainka, inability of critics to assess the works in time brings to huge amount of "opus posthumum” (2018, p. 451).

Lesia Ukrainka did not deny the realism, but was glad to an unexpected success of "science fiction among the audience of the elder family" (2018, p. 559). Although Lesia Ukrainka did not identify herself with any of literary generation, she thought of herself not simply in the context of the literary period but felt responsible for its development:

It is better to hear the condemnation of the work and refrain from printing it than to print a bad thing and with such a responsible topic! This is bad not just for me, but for our literature in general. (2018, p. 613)

\section{Conclusions}

We have the possibility to state that following the modern development of literature was a priority for Lesia Ukrainka; noticing the appearance of new high-art works that had its readers; being careful about her own manuscripts. Lesia Ukrainka respected the experience of the representatives of the previous generation, but the desire to be appreciated by critics as part of the present generation, the feeling of responsibility for the development of literature give reason to think that the writeress still identified herself as the representative of modernism.

However, accepting this identity was not easy or unambiguous for Lesia Ukrainka. She began with a national identity, choosing a pseudonym at the age of 13 following the example of her uncle. "But national identity also extends into the realm of culture and values. It consists of the stories that people tell about themselves: where they came from, what they celebrate, their shared historical memories, what it takes to become a genuine member of the community" (Fukuyama, 2018, p. 134). Without the consistent and varied 
communication that her family was provided to the young writeress, her entry into the system of literary generations would not have taken place.

But we must also keep in mind that the modernization of society and literature coincided with the spread of Friedrich Nietzsche's ideas about individualism. At the same time, "identity is rooted in thymos, which is experienced emotionally through feelings of pride, shame, and anger" (Fukuyama, 2018, p. 138). Thymos, "the third part of the soul" (Fukuyama, 2018, p. 27-37), is the engine of the search for identity in both directions - collectivistic and individualistic. Both are clearly visible in Lesia Ukrainka's letters. On the one hand, she seeks to outline her own conformity to the existence models that her environment offers. This is done through the expression of etiquette, involvement, and common values. However, it seems that none of the models completely satisfies the writeress. She has her own vision of her uniqueness, and the same thymos does not allow her to dissolve in a generation.

An outstanding writer does not necessarily identify himself/herself with certain generations, and does not necessarily clearly speaks about it in the epistolary or journalistic heritage. Sometimes the writer's belonging to the certain generation can be confirmed on the basis of secondary factors: subjective assessments of works of other writers, self-reflection, relations with literary criticism, etc.

\section{Bibliographic references}

Aheieva, V. (2001). Poetess of the turn of the century. Works of Lesia Ukrainka in postmodern interpretation. Kyiv: Lybid.

Aheieva, V. (2008). Women's space. Feminist discourse of Ukrainian modernism. Kyiv: Vysoka polytsia.

Biletskyi, L. (1951). Three silhouettes: Marko Vovchok - Olha Kobylianska - Lesia Ukrainka. Winnipeg; Trident Press. https://diasporiana.org.ua/literaturoznavstvo/17 330-biletskiy-l-tri-silvetki-marko-vovchokolga-kobilyanska-lesya-ukrayinka.

Demska-Budzuliak, L. (2005). "Change of generations - is it a real problem?". In L. Skupeiko (ed.). New history of Ukrainian literature (theoretical and methodological aspects). (pp. 170-173). Kyiv: Krytyka.

Drai-Khmara, M. (2002). Literary and scientific heritage. Kyiv: Naukova dumka.

Franko, I. (1984a). Ukrainian-Russian (Little Russian) literature. In: I. Franko. Collection of works in 50 volumes. (Vol. 41, pp. 74-100). Kyiv. https://chtyvo.org.ua/authors/Franko/Zibrannia _tvoriv_u_50_tomakh_t41.

Franko, I. (1984b). Ukrainians. In: I. Franko. Collection of works in 50 volumes (Vol. 41, pp. 162-193). Kyiv. https://chtyvo.org.ua/authors/Franko/Zibrannia _tvoriv_u_50_tomakh_t41.

Fukuyama, F. (2018). Identity: The demand for dignity and the politics of resentment. New York: Farrar, Straus and Giroux.

Hentea, M. (2013). The Problem of Literary Generations: Origins and Limitations. Comparative Literature Studies, 50(4), 567-588.

https://doi.org/10.5325/complitstudies.50.4.05 67

Ichim, L. (2012). Theories and Theorists of the Literary Generation Concept. Contemporary Semantic Re-evaluations and their Sociocultural Impact. Procedia - Social and Behavioral Sciences, 63, 283-287. https://doi.org/10.1016/j.sbspro.2012.10.040

Kon, I. (1976). Sociology of personality. Moscow: Politizdat.

Lefter, I. B. (2005). Flashback 1985: The beginnings of the new poetry. Piteşti: Ed. Paralela 45.

Perkins, D. (1992). Is literary history possible? Baltimore and London: Johns Hopkins University Press.

Scrypka, T. (Ed.). (2004). Larysa Petrivna KosachKvitka (Lesia Ukrainka): Biographical materials. Memoirs. Iconographic. Kyiv: Fakt.

Skupeiko, L. (2007). Persons and texts (form the history of Ukrainian literature). Kyiv: Phoenix.

Skupeiko, L. (Ed.). (2005). The new history of Ukrainian literature (theoretical and methodological aspects). Kyiv: Krytyka.

Ukrainka Lesia. (2016). Letters: 1876-1897. Kyiv: Komora.

Ukrainka Lesia. (2017). Letters: 1898-1902. Kyiv: Komora.

Ukrainka Lesia. (2018). Letters: 1903-1913. Kyiv: Komora.

Vianu, T. (1936). Generation and creation. Bucureşti.

Yefremov, S. (1995). History of Ukrainian writing. Kyiv: Femina.

Yemets-Dobronosova, Y. (2010). Destructiveness of literary history. Literary history (pp. 1-9). Kyiv: Smoloskyp.

Yevshan, M. (1998). Criticism. Literary Studies. Aesthetics. Kyiv: Osnovy. https://chtyvo.org.ua/authors/Yevshan_Mykola /Krytyka_Literaturoznavstvo_Estetyka.

Zerov, M. (2003). Ukrainian writing. Kyiv: Osnovy. 